\title{
The impact of protein supplementation on exercise- induced muscle damage, soreness and fatigue following prolonged walking exercise in older adults a randomized double-blind placebo-controlled trial
}

Dominique ten Haaf

Radboudumc

Coen C.W.G. Bongers

Radboudumc

Hugo G. Hulshof

Radboudumc

Thijs M.H. Eijsvogels ( $\square$ Thijs.Eijsvogels@radboudumc.nl )

Radboudumc https://orcid.org/0000-0003-0747-4471

Maria T.E. Hopman

Radboudumc

\section{Research}

Keywords: muscle damage, elderly, physical activity, endurance exercise

Posted Date: December 19th, 2019

DOI: https://doi.org/10.21203/rs.2.19249/v1

License: (a) (1) This work is licensed under a Creative Commons Attribution 4.0 International License.

Read Full License 


\section{Abstract}

Background Protein supplementation can enhance recovery of exercise-induced muscle damage in young adults. It is currently unknown whether this could be extrapolated to older adults who have a disturbed muscle protein synthetic response. The aim of this study was to assess whether protein supplementation could attenuate exercise-induced muscle damage and soreness after prolonged moderate-intensity walking exercise in older adults.

Methods In a double-blind, placebo-controlled intervention study, 104 participants (81\% male, BMI: $26.5 \pm 2.5 \mathrm{~kg} / \mathrm{m} 2)$ of 65 years or older used either a protein $(n=50)$ or placebo supplement $(n=54)$ during breakfast and directly after exercise cessation. Study participants walked 30/40/50 km per day on 3 consecutive days. Muscle soreness and fatigue were determined at baseline, and after the $1 \mathrm{st}$ and $3 \mathrm{rd}$ exercise day with a numeric rating scale. Blood samples, to measure plasma creatine kinase (CK) concentrations and serum inflammation markers, were obtained at baseline (pre-exercise), and after the 1 st and 3 rd exercise day.

Results Habitual protein intake was comparable between the protein $(0.92 \pm 0.27 \mathrm{~g} / \mathrm{kg} / \mathrm{d})$ and placebo group $(0.97 \pm 0.23 \mathrm{~g} / \mathrm{kg} / \mathrm{d}, P=0.31)$. At baseline, comparable CK concentrations were found between the protein and the placebo group (110 (IQR: 84-160 U/L) and 115 (IQR: 91-186 U/L), respectively, $\mathrm{P}=0.84$ ). Prolonged walking (protein: $32 \pm 9 \mathrm{~km} / \mathrm{d}$, placebo: $33 \pm 6 \mathrm{~km} / \mathrm{d}$ ) resulted in a cumulative increase of CK in both the protein ( $\Delta 283$ (IQR: 182-662 U/L)) and placebo group ( $\Delta 456$ (IQR: 209-885 U/L)) after three days. CK elevations were not significantly different between groups $(P=0.43)$. Similarly, no differences in inflammation markers, muscle soreness and fatigue were found between groups.

Conclusions In contrast to findings in young adults, protein supplementation does not attenuate exerciseinduced muscle damage, muscle soreness or fatigue in older adults performing prolonged moderateintensity walking exercise.

\section{Introduction}

Physical activities, i.e. resistance and endurance exercises, and especially weight-bearing exercise, result in micro injuries to contractile proteins, so-called muscle damage, as demonstrated by elevated muscle soreness and an increase in plasma creatine kinase (CK) (1). The intake of dietary proteins may augment muscle repair following acute damage through accelerating muscle protein turnover resulting in a positive net protein balance (2). Moreover, protein consumption following muscle-damaging exercise stimulates muscle satellite cell activity (3). Both could support the growth and repair of contractile proteins $(2,4)$. Indeed, several studies in young males have shown beneficial effects of protein supplementation on the extent of muscle damage after high-intensity endurance exercise (5-8).

In older adults, the muscle protein synthetic response to anabolic stimuli such as protein intake is attenuated $(9,10)$. The anabolic resistance in older adults is multifactorial, but includes a lower amino acids delivery to and uptake by ageing muscles, and an impaired mammalian target of rapamycin 
complex 1 (MTOR-1) pathway, which is essential for muscle protein synthesis $(9,10)$. Therefore, it has been suggested that older adults need higher total protein intake to counteract the attenuated postprandial muscle protein turnover (11). It is unclear whether improving the protein intake in older adults with supplements can reduce exercise-induced muscle damage after performing prolonged moderateintensity endurance exercise (3).

Therefore, the aim of the present study was to determine whether protein supplementation could attenuate exercise-induced muscle damage, muscle soreness and fatigue after performing prolonged moderate-intensity endurance exercise in older adults. We hypothesized that protein supplementation could improves recovery from endurance exercise.

\section{Methods}

\section{Participants}

The present study is a sub-analysis of a larger double-blind, placebo-controlled intervention study in which the CONSORT flow diagram can be found (12). Participants of $\geq 65$ years old with a habitual protein intake $\leq 1.0 \mathrm{~g} / \mathrm{kg} / \mathrm{d}$ that were registered for the 2017 Nijmegen Four Days Marches (an annual 4 day walking event $(30,40$, or $50 \mathrm{~km} /$ day) in the Netherlands; https://www.4daagse.nl/en] were randomly allocated to either a protein- or a placebo-supplemented group and participants and investigators were blinded for the intervention they received. Exclusion criteria for participation in the study were diabetes mellitus (non-fasted state $>11 \mathrm{mmol} / \mathrm{L}$, allergic or sensitive for milk proteins or lactose intolerant, COPD, cancer, renal insufficiency (estimated Glomerular Filtration Rate (EGFR) $<30 \mathrm{ml} / \mathrm{min} / 1.73 \mathrm{~m}^{-1}$ ), intestinal diseases, use of statins and involved in a heavy resistance type exercise program. All participants gave written informed consent prior to any experimental procedures. The study conformed to the principles of the Declaration of Helsinki and was approved by a local Medical Ethical committee (Independent Review Board Nijmegen, Study-ID: NL60137.072.16). This trial according to CONSORT guidelines was registered at Dutch trial registry (www.trialregister.nl - NTR6488).

\section{Study design}

114 participants performed walking exercise on three consecutive days (30, 40 or $50 \mathrm{~km} /$ day) and were instructed to use two supplements a day. Blood samples were collected between $12-36$ hours before the onset of exercise (baseline), and immediately after the first and third walking day to assess creatine kinase (CK) concentrations. The CK concentrations after the third walking day represented the cumulative CK concentrations 48 hours after the first walking day, 24 hours after the second day and directly after the third walking day. Muscle soreness and fatigue were determined at baseline, and after the first and third walking day with a numeric rating scale. Additionally, exercise characteristics, body composition, training history, dietary intake and inflammation markers were determined.

\section{Protein intervention}


Participants were instructed by a researcher to consume $250 \mathrm{ml}$ protein supplement (Milk Protein Concentrate (MPC)) or $250 \mathrm{ml}$ iso-caloric placebo drink during breakfast and were given a second supplement within 30 minutes after finishing the prolonged walking exercise at the research location. Moreover, in the 12 weeks prior to the prolonged walking event, both groups consumed also one supplement with breakfast and another one after exercise, or on non-exercising days, during lunch. The protein group received an additional $31 \mathrm{~g}$ of protein per day using the supplements, whereas the control group received placebo supplementation with carbohydrates (FrieslandCampina Consumer Products Europe, Wageningen, the Netherlands). Protein and placebo supplements were provided in ready-to-drink non-transparent packages of $250 \mathrm{ml}$ and were vanilla flavored to mask contents. Compliance was checked at the research location. Adverse events were documented.

\section{Measurements}

Body composition. Height and weight (Seca 888 scale, Hamburg, Germany) were measured and used to calculate the body mass index (BMI). Furthermore, waist and hip circumference were measured to calculate the waist-hip ratio.

Walking exercise. In the 12 weeks prior to the walking exercise event, participants reported their weekly walking exercise (in $\mathrm{km}$ ) in an online questionnaire. During the walking exercise event, distance (30, 40 or $50 \mathrm{~km}$ per day) and daily exercise duration were reported. On the first day of walking, heart rate was measured in triplicate, and averaged, every $5 \mathrm{~km}$ milestone with a 2-channel ECG chest band system (Polar Electro Oy, Kempele, Finland). Data was presented as mean heart rate (beats per minute, bpm) and exercise intensity, defined as a percentage of the predicted maximal heart rate (208-0.7 *age) (13).

Dietary intake. Habitual dietary intake was assessed in the week prior to the walking exercise event using a repeated $24 \mathrm{hr}$ recall, which is a validated method to assess the amount and distribution of protein intake (14). Two recall days were randomized over the week with the restriction that no participant was assigned to two identical week days or two weekend days. The $24 \mathrm{hr}$ recall was performed face-to-face or by phone by trained dieticians and coded by the same dieticians into the web-based program Compl-eat, which calculated the dietary intake using the Dutch Food Composition Database of 2016 (15). The mean of the two recorded days represented the daily dietary intake.

Muscle soreness. A validated Numeric Pain Rating Scale (NPRS; a segmented numeric version of the visual analog scale) (16) was used where participants could mark a pain score between no pain at all $(N P R S=0)$ and extremely painful (NPRS $=10)$ for their calves, thighs and glutes. NPRS scores of 1 - 5 were considered as mild pain, 6 - 7 as moderate pain and $\geq 8$ as severe pain (17).

Fatigue. The level of fatigue was determined with a numeric rating scale ranging from 0 (no fatigue) to 10 (worst imaginable level of fatigue).

Blood samples. Non-fasted venous blood was drawn from the antecubital vein and serum and lithium heparin samples were stored at $-80^{\circ} \mathrm{C}$ until further analysis. Plasma CK and C-reactive protein (CRP) were measured using Siemens Dimension Vista 1500 (Siemens Healthcare Diagnostics Inc., Tarrytown, New York, USA). The reference CK value for males is $<171$ unit per liter ( $\mathrm{U} / \mathrm{L}$ and for females $<145 \mathrm{U} / \mathrm{L}(18)$. Interleukin (IL) 6 and IL10 concentrations were determined using a multiplex electroluminescence-based 
cytokine assay on a MESO QuickPlex SQ120 plate imager (Meso Scale Diagnostics, Rockville, Maryland, USA). CRP, IL6 and IL10 were assessed to determine the level of inflammation. Analysis were performed by trained technicians using standard operating procedures, on a single day using the same calibration and set-up to minimize variation.

\section{Statistical analysis}

Statistical analyses were performed using SPSS 22.0 software (IBM SPSS Statistics for Windows, Version 22.0 IBM Corp., Armonk, NY, USA). A per-protocol analysis was used including only those participants that finished and completed all study procedures at baseline and on the first, second and third day of the Four Days Marches. All continuous variables were visually inspected and tested for normality with the Shapiro-Wilk test. Participant characteristics were displayed as mean \pm SD or median (interquartile range (IQR)) for parametric and non-parametric continuous variables, respectively. Muscle soreness and fatigue were presented as mean $\pm S D$, despite their non-parametric nature. Categorical variables were given as number of participants with percentages. Baseline characteristics, muscle soreness, fatigue levels, concentrations of inflammation markers and CK levels after day 1 and 3 were compared between groups using an independent-samples $t$ test or a Mann-Whitney $U$ test for parametric or non-parametric continuous variables, respectively. A chi-square or Fisher's exact test was used for categorical variables. Friedman test was used to assess if there was a time effect for muscle soreness, fatigue levels, concentrations of inflammation markers and CK concentrations over the multiple days. After checking for normality of the residuals, the change of CK between baseline and day 3 was analyzed using an ANCOVA with treatment group as a fixed factor and baseline CK as a covariate. The level of significance was set at $p<0.05$ (two-sided).

\section{Results}

\section{Participants}

Four participants dropped out on the first day, two on the second day and four on the third day because they were not able to complete the walking exercise; $n=9$ participants suffered from sports injuries and $n$ $=1$ participant reported a serious adverse event unrelated to the study (hospitalization because of arrhythmia). Although the reasons for dropouts were unrelated to the supplement, $n=8$ participants of the protein group dropped out compared to $n=2$ participants of the placebo group (Fisher's exact test: $P$ $=0.094)$.

The remaining $n=104$ participants consisted of $n=84$ males (81\%), aged 69 (IQR: 67-73) years with a BMl of $26.5 \pm 2.5 \mathrm{~kg} / \mathrm{m}^{2} . N=50$ participants were allocated to the protein group and $n=54$ to the placebo group. No differences were observed between both groups for demographics and body composition (Table 1).

The participants' exercise duration was $7.5 \pm 1.2 \mathrm{~h}$ on day 1 and $7.2 \pm 1.3 \mathrm{~h}$ on day 3 . The average exercise duration of the first day was longer for the protein group $(7.7 \pm 1.1 \mathrm{~h})$ compared to the placebo group $(7.2 \pm 1.3 \mathrm{~h}), P=0.022$ (Figure 1A). The average heart rate during walking on the first day was 104 
$\pm 18 \mathrm{bpm}$, which equals an exercise intensity of $67 \pm 12 \%$. No differences between the protein and placebo group were observed (Table 1 and Figure 1B). Moreover, the trained kilometers prior to the exercise event and walking distance during the event were not different between groups (Table 1).

Table 1 should be placed around here.

\section{Dietary intake}

Baseline habitual protein intake (disregarding supplements) was comparable between the protein and placebo group $(0.92 \pm 0.27 \mathrm{~g} / \mathrm{kg} / \mathrm{d}$ and $0.97 \pm 0.23 \mathrm{~g} / \mathrm{kg} / \mathrm{d}$, respectively, $P=0.31)$. In the protein group $n=$ 17 participants (34\%) were below the general protein recommendation of $0.8 \mathrm{~g} / \mathrm{kg} / \mathrm{d}$ and $n=14$ participants $(26 \%)$ of the placebo group were below $0.8 \mathrm{~g} / \mathrm{kg} / \mathrm{d}(P=0.37)$. There were no differences between the protein and placebo group for energy intake, protein distribution, protein source and macronutrient intake (Table 1). Compliance of supplementation intake at breakfast and after finishing the walking exercise was $100 \%$, resulting in a total protein intake of $1.28 \pm 0.28 \mathrm{~g} / \mathrm{kg} / \mathrm{d}$ within the protein group.

\section{Muscle soreness and fatigue}

Muscle soreness in the calves, thighs and glutes and fatigue levels were similar between the protein and placebo group at baseline (all $P>0.05$, Table 2). Significant increases over time from baseline until after the $3^{\text {rd }}$ walking day, were found for the calves $(P<0.001)$ and the thighs $(P<0.001)$, but not for the glutes $(P=0.12)$. Between the protein and the placebo group, no differences were observed for muscle soreness in all muscle groups after day 1 and day 3 (all $P>0.05$, Table 2). Similarly, categorical analysis revealed no differences between groups on all days (all $P>0.05$, Table 3 ).

A significant time effect from baseline until after day 3 was found for fatigue levels $(P<0.001)$, but fatigue levels were similar across groups at baseline, after day 1 and day 3 (all $P>0.05$, Table 2).

Table 2 and 3 should be placed around here.

\section{Blood analyses}

At baseline, no significant differences were found in the CK concentrations between the protein and the placebo group (110 (IQR: $84-160) \mathrm{U} / \mathrm{L}$ and 115 (IQR: 91 - 186) U/L, respectively, $P=0.84$ ). Elevated CK levels were found in the protein group after day 1: $254(175-445) \mathrm{U} / \mathrm{L}$ and day 3: 433 (IQR: 288 - 803) $\mathrm{U} / \mathrm{L}$ ), and in the placebo group (day 1: 301 (188 - 469) U/L and day 3: 622 (IQR: 321 - 1053) U/L after 
prolonged walking for three consecutive days, $P_{\text {Time }}<0.001$. No significant differences between groups were observed after day 1 and day 3 (Figure 2).

At baseline $n=11$ participants (22\%) of the protein group had CK concentrations above the reference value, which increased to $n=40$ participants (80\%) after day 1 and $n=49$ participants (98\%) after day 3 . In the placebo group, $n=16$ participants (30\%), $n=47$ participants $(87 \%)$ and $n=52(96 \%)$ had a CK concentrations above the reference value at baseline, after day 1 and after day 3 , respectively. The number of participants that had CK concentrations above the reference value were not significantly different between both groups at baseline, after day 1 and after day $3(P=0.38, P=0.60$ and $P=0.53$, respectively). Furthermore, the increase in CK between baseline and day 3 was not significantly different between the protein $(\Delta 283$ (IQR: $182-662) \mathrm{U} / \mathrm{L}$ ) and placebo group $(\Delta 456$ (IQR: $209-885) \mathrm{U} / \mathrm{L}), P=$ 0.43 .

The inflammatory markers CRP, IL6 and IL10 were similar between the protein and placebo group at baseline (all $P>0.05$, Table 4). Significant changes over time were seen from baseline to day 3 for CRP, IL6 and IL10 (all $P<0.001$ ). No group differences were observed after day 1 (all $P>0.05$, Table 4), but a tendency towards lower values of IL6 and IL10 concentrations (both $P=0.06$ ) was found for the protein group at Day 3 (Table 4).

Table 4 should be placed around here.

\section{Discussion}

We were the first to assess the effect of protein supplementation on exercise-induced muscle damage after single and repetitive bouts of consecutive prolonged moderate-intensity exercise among older adults. We found a heterogeneous response in CK elevations following prolonged walking (30/40/50 km), with post-exercise CK levels of 286 (IQR: 177-461) U/L and 555 (IQR: 294-933) U/L on day 1 and 3, respectively. Protein supplementation successfully increased daily protein intake levels, but did not impact exercise-induced muscle damage as similar CK responses were found between the protein and placebo group. Moreover, we found no differences in muscle soreness and fatigue between groups. These findings indicate that the exercise-induced muscle damage in older adults is rather high and alternative strategies to reduce damage in the ageing muscle are warranted.

The cumulative CK following prolonged walking for three consecutive days was 555 (IQR: 294-933 U/L) in participants aged 65 years or older, whereas reference values of $<171 \mathrm{U} / \mathrm{L}$ for males and $<145 \mathrm{U} / \mathrm{L}$ for females are reported (18). Exercise-induced elevated CK levels have been proposed to be the result of leakage from muscle fibers following the mechanical tearing of the sarcolemma and opening of stretchactivated channels following contraction-induced damage (19). A previous study has shown that highintensity, short duration resistance exercise resulted in greater CK concentrations compared to lowintensity exercise for a longer duration (20). However, the CK concentrations found after prolonged 
moderate-intensity walking exercise in our study are comparable with peak CK levels within 24-72 hours $(\sim 480 \mathrm{U} / \mathrm{L})$ after performing 40 minutes of downhill walking in young adults $(21,22)$. Moreover, $26 \mathrm{~km}$ of running-exercise resulted in peak CK levels of $\sim 360 \mathrm{U} / \mathrm{L}$ among males with an average age of 35 years (23). Our findings emphasize that not only short-term vigorous-intensity activities induce muscle damage, but prolonged weight-bearing moderate-intensity activity performed by older adults leads to a similar or an even higher increase in CK.

Muscles of older adults often exhibit higher levels of damage and/or slower recovery rates compared to younger peers $(19,24)$. In older adults only limited studies have been performed to determine the exerciseinduced muscle damage measured by CK. After performing maximal eccentric knee extensions, peak changes in CK levels varied from $\sim \Delta 20-\sim \Delta 280 \mathrm{U} / \mathrm{L}$ within $24-48$ hours in adults $>60$ years of age $(25$, 26). One study assessed CK elevations after an incremental cycle ergometer test to exhaustion in older adults, but measured CK already 5 minutes after exercise ( $\sim 25 \mathrm{U} / L)(27)$ while peak CK levels are often found $24-48 \mathrm{~h}$ after exercise. Moreover, the moderate-intensity endurance activity performed by our study population was much more prolonged. This explains the greater CK elevations found in our study.

Supplemental protein has been shown to stimulate protein synthesis with concomitant reductions in protein breakdown, which is critical in remodeling damaged muscle tissue $(28-30)$. However, with increasing the protein intake from $0.97 \pm 0.23 \mathrm{~g} / \mathrm{kg} / \mathrm{d}$ to $1.28 \pm 0.28 \mathrm{~g} / \mathrm{kg} / \mathrm{d}$ within the protein group, which is in accordance with the recommendation of $\geq 1.2 \mathrm{~g} / \mathrm{kg} / \mathrm{d}$ for physically active older adults (11), we found no protective effect on exercise-induced CK elevations or muscle soreness. Our findings are in accordance with a study that supplemented young males with $100 \mathrm{~g}$ of protein immediately after 30 minutes of downhill running that found no differences in plasma CK concentrations and muscle soreness compared to placebo (4). On the contrary, other studies in young males did find approximately $\sim 200 \mathrm{U} / \mathrm{L}$ lower CK levels and lower muscle soreness at 24 hours after high-intensity endurance exercise with protein supplementation compared to controls (5-8). The supplementation strategies in these studies varied from preloading supplementation for weeks before the exercise to supplementation directly before, during exercise and post-exercise with amounts varying between $2.5 \mathrm{~g}$ to $100 \mathrm{~g}$ of protein (5-8). As our study was part of a larger study of 13 weeks, preloading of the protein intake also took place for our participants in the 12 weeks before the walking exercise event. Moreover, $15.5 \mathrm{~g}$ of the total $31 \mathrm{~g}$ of protein of the day were used within 30 minutes after the exercise, in which the exercise-induced muscle protein synthetic response and enhanced preservation of skeletal muscle sensitivity to dietary amino acids is the highest (31-33). Therefore, the supplementation strategy (amount and timing) in our study do presumable not explain the contradicting findings with earlier performed studies. However, the mentioned studies are performed in young adults, whereas the anabolic resistance in older adults in our study could maybe limit the efficiency of the protein supplementation. Unfortunately only one study was found that assessed the effect of a high versus a low protein intake (three protein boluses of 3.0 versus $6.0 \mathrm{~g} / \mathrm{kg}$, respectively) within 2 hours after 30 min downhill running and after a cycling time trial on exercise-induced muscle damage in (somewhat) older adults (age $52 \pm 2$ ) (34). Although myoglobin concentrations were determined as a marker of muscle damage instead of CK, similar to our results, no statistical differences between the protein supplementation strategies were reported for muscle damage 
marker and muscle soreness after both trials (34). Thus, it seems that the age-related anabolic resistance in older adults limits the possible beneficial effects of protein supplementation on exercise-induced muscle damage and soreness.

With the increasing life expectancy across the globe, the subpopulation of older adults is growing fast. In Europe a quarter of the population is already aged $\geq 60$ years and that proportion is estimated to reach $35 \%$ in 2050 (35). To maintain the ability to remain physically active during ageing, which results in many health benefits (36), reduced exercise-induced muscle damage is favorable, especially since muscle damage is not associated with skeletal muscle hypertrophy (37), whereas the consequent muscle soreness does hinder people to exercise. Therefore, it is important to assess whether protein supplementation could reduce exercise-induced muscle damage. Unfortunately, there remains a paucity of data within older adults on this topic (3). Our research indicates that it is harder to reduce exerciseinduced muscle damage in older adults, while in younger adults often promising results are found. More studies are warranted to determine whether an even higher protein intake, possibly given during the exercise, or other strategies like creatine monohydrate and omega-3 fatty acids (3), could reduce exerciseinduced muscle damage in older adults.

A limitation of the study was that we did not measure dietary intake during the exercise bouts and therefore the participants protein intake is unknown during these 3 days on which they have walked for 7.0-7.5 hours. However, the habitual diet during the week before the walking event demonstrated similar protein intake between the protein and placebo group. We expect, therefore, no differences in protein intake between groups during the walking exercise in our large randomized group of $n=104$ participants.

\section{Conclusion}

In older adults performing prolonged moderate-intensity walking exercise, protein supplementation at breakfast and directly after exercise did not attenuate the exercise-induced muscle damage, shown by large and comparable increases in CK in the protein and placebo group after three days of consecutive walking exercise. Moreover, muscle soreness and fatigue were not affected by protein supplementation.

\section{Declarations}

\section{Ethics approval and consent to participate}

All participants gave written informed consent prior to any experimental procedures. The study conformed to the principles of the Declaration of Helsinki and was approved by a local Medical Ethical committee (Independent Review Board Nijmegen, Study-ID: NL60137.072.16, Independent Review Board reference number: IRBN2016017).

\section{Consent for publication}

Not applicable. 
Availability of data and materials

The datasets used and/or analysed during the current study are available from the corresponding author on reasonable request.

\section{Competing interests}

The authors declare that they have no competing interests.

\section{Funding}

This research was funded by the "Topconsortia voor Kennis en Innovatie (TKI's)" from the ministry of Ministry of Economic Affairs, "TKI Agri \& Food", the Netherlands.

\section{Authors' contributions}

$\mathrm{DtH}, \mathrm{TE}$ and $\mathrm{MH}$ contributed to the conception and design of the study. $\mathrm{DtH}, \mathrm{CB}, \mathrm{HH}, \mathrm{TE}$ and $\mathrm{MH}$ contributed to the acquisition of the data. DtH contributed to the analysis of the data. DtH, TE and MH contributed to the interpretation of the data. $\mathrm{DtH}, \mathrm{CB}, \mathrm{HH}, \mathrm{TE}$ and $\mathrm{MH}$ contributed to the draft of the paper. All authors read and approved the final manuscript.

\section{Acknowledgements}

The authors greatly acknowledge the enthusiasm and dedication of the participants in this study. Furthermore, the practical assistance of colleagues was greatly appreciated.

\section{Authors' information}

Not applicable.

\section{References}

1. Brancaccio P, Maffulli N, Limongelli FM. Creatine kinase monitoring in sport medicine. British medical bulletin. 2007;81-82:209-30.

2. Biolo G, Maggi SP, Williams BD, Tipton KD, Wolfe RR. Increased rates of muscle protein turnover and amino acid transport after resistance exercise in humans. Am J Physiol. 1995;268(3 Pt 1):E514-20.

3. Clifford T. Nutritional and Pharmacological Interventions to Expedite Recovery Following MuscleDamaging Exercise in Older Adults: A Narrative Review of the Literature. Journal of aging and physical activity. 2019:1-15.

4. Etheridge T, Philp A, Watt PW. A single protein meal increases recovery of muscle function following an acute eccentric exercise bout. Applied physiology, nutrition, and metabolism = Physiologie appliquee, nutrition et metabolisme. 2008;33(3):483-8.

5. Coombes JS, McNaughton LR. Effects of branched-chain amino acid supplementation on serum creatine kinase and lactate dehydrogenase after prolonged exercise. The Journal of sports medicine and physical fitness. 2000;40(3):240-6.

6. Greer BK, Woodard JL, White JP, Arguello EM, Haymes EM. Branched-chain amino acid supplementation and indicators of muscle damage after endurance exercise. Int J Sport Nutr Exerc Metab. 2007;17(6):595-607. 
7. Huang WC, Chang YC, Chen YM, Hsu YJ, Huang CC, Kan NW, et al. Whey Protein Improves MarathonInduced Injury and Exercise Performance in Elite Track Runners. Int J Med Sci. 2017;14(7):648-54.

8. Valentine RJ, Saunders MJ, Todd MK, St Laurent TG. Influence of carbohydrate-protein beverage on cycling endurance and indices of muscle disruption. Int J Sport Nutr Exerc Metab. 2008;18(4):363-78.

9. Breen L, Phillips SM. Skeletal muscle protein metabolism in the elderly: Interventions to counteract the 'anabolic resistance' of ageing. Nutrition \& metabolism. 2011;8:68.

10. Burd NA, Gorissen SH, van Loon LJ. Anabolic resistance of muscle protein synthesis with aging. Exercise and sport sciences reviews. 2013;41(3):169-73.

11. Bauer J, Biolo G, Cederholm T, Cesari M, Cruz-Jentoft AJ, Morley JE, et al. Evidence-based recommendations for optimal dietary protein intake in older people: a position paper from the PROTAGE Study Group. Journal of the American Medical Directors Association. 2013;14(8):542-59.

12. Ten Haaf DSM, Eijsvogels TMH. Protein supplementation improves lean body mass in physically active older adults: a randomized placebo-controlled trial. 2019;10(2):298-310.

13. Tanaka H, Monahan KD, Seals DR. Age-predicted maximal heart rate revisited. J Am Coll Cardiol. 2001;37(1):153-6.

14. Crispim SP, de Vries JH, Geelen A, Souverein OW, Hulshof PJ, Lafay L, et al. Two non-consecutive 24 $\mathrm{h}$ recalls using EPIC-Soft software are sufficiently valid for comparing protein and potassium intake between five European centres-results from the European Food Consumption Validation (EFCOVAL) study. The British journal of nutrition. 2011;105(3):447-58.

15. . RIVM. NEVO online version 2013/4.0. Bilthoven: RIVM; 2013.

16. Hjermstad MJ, Fayers PM, Haugen DF, Caraceni A, Hanks GW, Loge JH, et al. Studies comparing Numerical Rating Scales, Verbal Rating Scales, and Visual Analogue Scales for assessment of pain intensity in adults: a systematic literature review. Journal of pain and symptom management. 2011;41(6):1073-93.

17. Boonstra AM, Stewart RE, Koke AJ, Oosterwijk RF, Swaan JL, Schreurs KM, et al. Cut-Off Points for Mild, Moderate, and Severe Pain on the Numeric Rating Scale for Pain in Patients with Chronic Musculoskeletal Pain: Variability and Influence of Sex and Catastrophizing. Frontiers in psychology. 2016;7:1466.

18. Schumann G, Klauke R. New IFCC reference procedures for the determination of catalytic activity concentrations of five enzymes in serum: preliminary upper reference limits obtained in hospitalized subjects. Clinica chimica acta; international journal of clinical chemistry. 2003;327(1-2):69-79.

19. Baumert P, Lake MJ, Stewart CE, Drust B, Erskine RM. Genetic variation and exercise-induced muscle damage: implications for athletic performance, injury and ageing. European journal of applied physiology. 2016;116(9):1595-625.

20. Tiidus PM, lanuzzo CD. Effects of intensity and duration of muscular exercise on delayed soreness and serum enzyme activities. Med Sci Sports Exerc. 1983;15(6):461-5.

21. Maeo S, Ochi Y, Yamamoto M, Kanehisa H, Nosaka K. Effect of a prior bout of preconditioning exercise on muscle damage from downhill walking. Applied physiology, nutrition, and metabolism = 
Physiologie appliquee, nutrition et metabolisme. 2015;40(3):274-9.

22. Maeo S, Yamamoto $M$, Kanehisa $H$. Downhill walking training with and without exercise-induced muscle damage similarly increase knee extensor strength. J Sports Sci. 2016;34(21):2018-26.

23. Quinn TJ, Manley MJ. The impact of a long training run on muscle damage and running economy in runners training for a marathon. Journal of Exercise Science \& Fitness. 2012;10(2):101-6.

24. Easthope CS, Hausswirth C, Louis J, Lepers R, Vercruyssen F, Brisswalter J. Effects of a trail running competition on muscular performance and efficiency in well-trained young and master athletes. European journal of applied physiology. 2010;110(6):1107-16.

25. Nogueira FR, Libardi CA, Nosaka K, Vechin FC, Cavaglieri CR, Chacon-Mikahil MP. Comparison in responses to maximal eccentric exercise between elbow flexors and knee extensors of older adults. Journal of science and medicine in sport. 2014;17(1):91-5.

26. Chen TC, Tseng WC, Huang GL, Chen HL, Tseng KW, Nosaka K. Low-intensity eccentric contractions attenuate muscle damage induced by subsequent maximal eccentric exercise of the knee extensors in the elderly. European journal of applied physiology. 2013;113(4):1005-15.

27. Bouzid MA, Hammouda O, Matran R, Robin S, Fabre C. Changes in oxidative stress markers and biological markers of muscle injury with aging at rest and in response to an exhaustive exercise. PLoS One. 2014;9(3):e90420.

28. Biolo G, Tipton KD, Klein S, Wolfe RR. An abundant supply of amino acids enhances the metabolic effect of exercise on muscle protein. Am J Physiol. 1997;273(1 Pt 1):E122-9.

29. Witard OC, McGlory C, Hamilton DL, Phillips SM. Growing older with health and vitality: a nexus of physical activity, exercise and nutrition. Biogerontology. 2016;17(3):529-46.

30. Phillips SM. A brief review of critical processes in exercise-induced muscular hypertrophy. Sports Med. 2014;44 Suppl 1:S71-7.

31. Aguirre LE, Villareal DT. Physical Exercise as Therapy for Frailty. Nestle Nutrition Institute workshop series. 2015;83:83-92.

32. Moore DR. Keeping older muscle "young" through dietary protein and physical activity. Adv Nutr. 2014;5(5):599S-607S.

33. Phillips SM, Tipton KD, Aarsland A, Wolf SE, Wolfe RR. Mixed muscle protein synthesis and breakdown after resistance exercise in humans. Am J Physiol. 1997;273(1 Pt 1):E99-107.

34. Doering TM, Reaburn PR, Borges NR, Cox GR, Jenkins DG. The Effect of Higher Than Recommended Protein Feedings Post-Exercise on Recovery Following Downhill Running in Masters Triathletes. Int $\mathrm{J}$ Sport Nutr Exerc Metab. 2017;27(1):76-82.

35. Maeo S, Yamamoto M, Kanehisa H, Nosaka K. Prevention of downhill walking-induced muscle damage by non-damaging downhill walking. PLoS One. 2017;12(3):e0173909.

36. Thompson PD, Eijsvogels TMH. New Physical Activity Guidelines: A Call to Activity for Clinicians and Patients. Jama. 2018;320(19):1983-4. 
37. Damas F, Libardi CA, Ugrinowitsch C. The development of skeletal muscle hypertrophy through resistance training: the role of muscle damage and muscle protein synthesis. European journal of applied physiology. 2018;118(3):485-500.

\section{Tables}

Table 1. Baseline characteristics of participants in the protein and placebo group

\begin{tabular}{|c|c|c|c|c|}
\hline & $\begin{array}{c}\text { Total group } \\
n=104\end{array}$ & $\begin{array}{c}\text { Protein } \\
\mathrm{n}=50\end{array}$ & $\begin{array}{c}\text { Placebo } \\
n=54\end{array}$ & $\begin{array}{c}\mathrm{P}- \\
\text { value }\end{array}$ \\
\hline \multicolumn{5}{|l|}{ Demographics } \\
\hline Age, yr & $69(67-73)$ & $69(67-72)$ & $69(67-73)$ & $0.96^{*}$ \\
\hline Male, n (\%) & $84(81)$ & $40(80)$ & $44(82)$ & $0.85^{\ddagger}$ \\
\hline \multicolumn{5}{|l|}{ Body composition } \\
\hline Body weight, kg & $82.2 \pm 10.4$ & $83.4 \pm 10.3$ & $81.1 \pm 10.4$ & $0.27^{\S}$ \\
\hline BMI, $\mathrm{kg} / \mathrm{m}^{2}$ & $26.5 \pm 2.5$ & $26.7 \pm 2.6$ & $26.3 \pm 2.4$ & $0.40^{\S}$ \\
\hline Waist-hip ratio & $0.93 \pm 0.07$ & $0.93 \pm 0.08$ & $0.92 \pm 0.07$ & $0.92^{\S}$ \\
\hline \multicolumn{5}{|l|}{ Diet } \\
\hline Energy intake, kcal & $1948 \pm 514$ & $1932 \pm 505$ & $1962 \pm 527$ & $0.77^{\S}$ \\
\hline Protein intake, $\mathrm{g} / \mathrm{kg} / \mathrm{d}$ & $0.94 \pm 0.25$ & $0.92 \pm 0.27$ & $0.97 \pm 0.23$ & $0.31^{\S}$ \\
\hline Protein intake at breakfast, $g$ & $12.0 \pm 6.1$ & $11.0 \pm 4.9$ & $13.1 \pm 6.9$ & $0.08^{\S}$ \\
\hline Protein intake at lunch, $g$ & $19.5 \pm 10.0$ & $18.7 \pm 10.9$ & $20.3 \pm 9.2$ & $0.42^{\S}$ \\
\hline Protein intake at dinner, $g$ & $35.7 \pm 14.5$ & $33.3 \pm 15.6$ & $37.9 \pm 13.2$ & $0.11^{\S}$ \\
\hline Animal protein, \% & $61.6 \pm 10.4$ & $61.7 \pm 9.6$ & $61.4 \pm 11.3$ & $0.88^{\S}$ \\
\hline Plant protein, \% & $38.0 \pm 10.6$ & $37.6 \pm 9.9$ & $38.5 \pm 11.2$ & $0.68^{\S}$ \\
\hline Protein, en\% & $16.4 \pm 3.1$ & $16.3 \pm 3.3$ & $16.5 \pm 3.0$ & $0.72^{\S}$ \\
\hline Fat intake, en\% & $36.1 \pm 6.7$ & $35.5 \pm 7.1$ & $36.7 \pm 6.4$ & $0.37^{\S}$ \\
\hline Carbohydrate intake, en $\%$ & $41.9 \pm 7.7$ & $42.9 \pm 7.8$ & $40.9 \pm 7.5$ & $0.17^{\S}$ \\
\hline \multicolumn{5}{|l|}{ Walking exercise } \\
\hline 12 wk pre-event training, $\mathrm{km}$ & $\begin{array}{c}385(257- \\
516)\end{array}$ & $\begin{array}{c}396(288- \\
539)\end{array}$ & $\begin{array}{c}341(244- \\
505)\end{array}$ & $0.41^{*}$ \\
\hline \multicolumn{4}{|l|}{ Distance per day } & \multirow[t]{4}{*}{$0.58^{\ddagger}$} \\
\hline 30 km, n (\%) & $72(71)$ & $32(67)$ & $40(74)$ & \\
\hline 40 km, n (\%) & $25(25)$ & $14(29)$ & $11(20)$ & \\
\hline $50 \mathrm{~km}, \mathrm{n}(\%)$ & $5(5)$ & $2(4)$ & $3(6)$ & \\
\hline Mean distance per day, km & $33 \pm 6$ & $32 \pm 9$ & $33 \pm 6$ & $0.60^{\S}$ \\
\hline Heart rate $(\mathrm{bpm})$ & $104 \pm 18$ & $102 \pm 17$ & $106 \pm 19$ & $0.28^{\S}$ \\
\hline Exercise intensity (\% from & & $66 \pm 11$ & $68 \pm 13$ & $0.30^{\S}$ \\
\hline $\left.\mathrm{HR}_{\max }\right)$ & $67 \pm 12$ & & & \\
\hline
\end{tabular}

Data are presented as number (percentage) of participants, mean \pm SD or median (interquartile range (IQR)).

BMI, Body mass index; bpm, beats per minute; en\%, energy percentage; $\mathrm{HR}_{\max }$, predicted maximal heart rate.

$\S$ Derived by independent-samples t-test. * Derived by Mann-Whitney U test. ${ }^{\ddagger}$ Derived by Chisquare test.

Table 2. Muscle soreness and fatigue during moderate-intensity exercise 


\begin{tabular}{|c|c|c|c|c|c|c|c|c|c|}
\hline & \multicolumn{3}{|c|}{ Baseline } & \multicolumn{3}{|c|}{ Day 1} & \multicolumn{3}{|c|}{ Day 3} \\
\hline & $\begin{array}{c}\text { Protein } \\
\mathrm{n}=50\end{array}$ & $\begin{array}{c}\begin{array}{c}\text { Placebo } \\
n=54\end{array} \\
\end{array}$ & $\begin{array}{c}\mathrm{P} \\
\text { value }\end{array}$ & $\begin{array}{c}\text { Protein } \\
n=50\end{array}$ & $\begin{array}{c}\begin{array}{c}\text { Placebo } \\
\mathrm{n}=54\end{array} \\
\end{array}$ & $\begin{array}{c}\mathrm{P} \\
\text { value }\end{array}$ & $\begin{array}{c}\text { Protein } \\
n=50\end{array}$ & $\begin{array}{c}\begin{array}{c}\text { Placebo } \\
n=54\end{array} \\
\end{array}$ & $\begin{array}{c}\mathrm{P} \\
\text { value }\end{array}$ \\
\hline Calves & $\begin{array}{c}1.16 \pm \\
0.47\end{array}$ & $\begin{array}{c}1.15 \pm \\
0.57\end{array}$ & 0.50 & $\begin{array}{c}1.53 \pm \\
0.87\end{array}$ & $\begin{array}{c}1.69 \pm \\
1.19\end{array}$ & 0.72 & $\begin{array}{c}1.66 \pm \\
1.36\end{array}$ & $\begin{array}{c}1.64 \pm \\
1.34\end{array}$ & 0.89 \\
\hline Thighs & $\begin{array}{c}1.10 \pm \\
0.36\end{array}$ & $\begin{array}{c}1.11 \pm \\
0.51\end{array}$ & 0.67 & $\begin{array}{c}1.70 \pm \\
1.17\end{array}$ & $\begin{array}{c}1.71 \pm \\
1.54\end{array}$ & 0.51 & $\begin{array}{c}1.83 \pm \\
1.47\end{array}$ & $\begin{array}{c}1.68 \pm \\
1.08\end{array}$ & 0.95 \\
\hline Glutes & $\begin{array}{c}1.24 \pm \\
0.63\end{array}$ & $\begin{array}{c}1.13 \pm \\
0.74 \\
\end{array}$ & 0.08 & $\begin{array}{c}1.43 \pm \\
1.15\end{array}$ & $\begin{array}{c}1.37 \pm \\
1.18 \\
\end{array}$ & 0.72 & $\begin{array}{c}1.34 \pm \\
0.92\end{array}$ & $\begin{array}{c}1.24 \pm \\
0.72 \\
\end{array}$ & 0.83 \\
\hline Fatigue & $\begin{array}{c}1.51 \pm \\
1.31\end{array}$ & $\begin{array}{c}1.32 \pm \\
0.73\end{array}$ & 0.42 & $\begin{array}{c}3.98 \pm \\
2.06\end{array}$ & $\begin{array}{c}4.15 \pm \\
1.74\end{array}$ & 0.44 & $\begin{array}{c}3.67 \pm \\
1.39\end{array}$ & $\begin{array}{c}3.76 \pm \\
1.80\end{array}$ & 0.93 \\
\hline
\end{tabular}

Table 3. Categorical analysis of muscle soreness during moderate-intensity exercise

Table 4. Blood analysis during moderate-intensity exercise

\begin{tabular}{|c|c|c|c|c|c|c|c|c|c|}
\hline & \multicolumn{3}{|c|}{ Baseline } & \multicolumn{3}{|c|}{ Day 1} & \multicolumn{3}{|c|}{ Day 3} \\
\hline & $\begin{array}{l}\text { tein } \\
=50\end{array}$ & $\begin{array}{c}\begin{array}{c}\text { Placebo } \\
\mathrm{n}=54\end{array} \\
\end{array}$ & $\begin{array}{c}\mathrm{P} \\
\text { value }\end{array}$ & $\begin{array}{c}\text { Protein } \\
\mathrm{n}=50\end{array}$ & $\begin{array}{c}\begin{array}{c}\text { Placebo } \\
\mathrm{n}=54\end{array} \\
\end{array}$ & $\begin{array}{c}P \\
\text { value }\end{array}$ & $\begin{array}{c}\text { Protein } \\
\mathrm{n}=50\end{array}$ & $\begin{array}{c}\begin{array}{c}\text { Placebo } \\
\mathrm{n}=54\end{array} \\
\end{array}$ & $\begin{array}{c}\mathrm{P} \\
\text { value }\end{array}$ \\
\hline \multicolumn{10}{|c|}{ Blood analysis } \\
\hline $\begin{array}{l}\mathrm{CRP} \\
\mathrm{mg} / \mathrm{L}\end{array}$ & $\begin{array}{l}2.9 \\
(2.9- \\
2.9)\end{array}$ & $\begin{array}{l}2.9 \\
(2.9- \\
2.9)\end{array}$ & 0.97 & $\begin{array}{l}2.9 \\
(2.9- \\
2.9)\end{array}$ & $\begin{array}{l}2.9 \\
(2.9- \\
2.9)\end{array}$ & 0.92 & $\begin{array}{l}9.0 \\
(4.0- \\
16.8)\end{array}$ & $\begin{array}{r}10.0 \\
(4.8- \\
14.6)\end{array}$ & 0.73 \\
\hline $\begin{array}{l}\text { IL-6, } \\
\mathrm{pg} / \mathrm{mL}\end{array}$ & $\begin{array}{l}0.69 \\
(0.46- \\
0.90)\end{array}$ & $\begin{array}{l}0.69 \\
(0.43- \\
0.97)\end{array}$ & 0.93 & $\begin{array}{c}5.58 \\
(3.39- \\
11.05)\end{array}$ & $\begin{array}{c}6.49 \\
(4.65- \\
10.93)\end{array}$ & 0.33 & $\begin{array}{l}1.86 \\
(1.20- \\
2.83)\end{array}$ & $\begin{array}{l}2.40 \\
(1.41- \\
5.46)\end{array}$ & 0.06 \\
\hline $\begin{array}{l}\text { IL-10, } \\
\mathrm{pg} / \mathrm{mL}\end{array}$ & $\begin{array}{l}0.20 \\
(0.13- \\
0.32)\end{array}$ & $\begin{array}{l}0.21 \\
(0.12- \\
0.30)\end{array}$ & 0.87 & $\begin{array}{l}0.33 \\
(0.19- \\
0.67)\end{array}$ & $\begin{array}{c}0.38 \\
(0.25 \\
-0.64)\end{array}$ & 0.35 & $\begin{array}{l}0.19 \\
(0.10- \\
0.26)\end{array}$ & $\begin{array}{l}0.24 \\
(0.16- \\
0.38)\end{array}$ & 0.06 \\
\hline \multicolumn{10}{|c|}{$\begin{array}{l}\text { Data are presented as median (interquartile range (IQR)). } \\
\text { CRP, C-reactive protein; IL, Interleukin. }\end{array}$} \\
\hline
\end{tabular}

\section{Figures}




\begin{tabular}{|c|c|c|c|c|c|c|c|c|c|}
\hline & \multicolumn{3}{|c|}{ Baseline } & \multicolumn{3}{|c|}{ Day 1} & \multicolumn{3}{|c|}{ Day 3} \\
\hline & otein & Placebo & $\begin{array}{c}\mathrm{P} \\
\text { value }\end{array}$ & Protein & Placebo & $\begin{array}{c}\mathrm{P} \\
\text { value }\end{array}$ & Protein & Placebo & $\begin{array}{c}\mathrm{P} \\
\text { value }\end{array}$ \\
\hline \multicolumn{10}{|l|}{ Calves } \\
\hline No pain & $\begin{array}{c}44 \\
(88)\end{array}$ & 49 (92) & 0.52 & $\begin{array}{c}31 \\
(69)\end{array}$ & 34 (67) & 1.00 & $\begin{array}{l}33 \\
(70)\end{array}$ & 34 (38) & 0.87 \\
\hline Mild pain & $\begin{array}{c}6 \\
(12)\end{array}$ & $4(8)$ & & $\begin{array}{l}14 \\
(28)\end{array}$ & $16(31)$ & & $\begin{array}{l}13 \\
(28)\end{array}$ & $15(30)$ & \\
\hline $\begin{array}{l}\text { Moderate } \\
\text { pain }\end{array}$ & $\begin{array}{c}0 \\
(0)\end{array}$ & $0(0)$ & & $0(0)$ & $1(2)$ & & $1(2)$ & $1(2)$ & \\
\hline $\begin{array}{l}\text { Severe } \\
\text { pain }\end{array}$ & $\begin{array}{c}0 \\
(0)\end{array}$ & $0(0)$ & & $0(0)$ & $0(0)$ & & $0(0)$ & $0(0)$ & \\
\hline \multicolumn{10}{|l|}{ Thighs } \\
\hline No pain & $\begin{array}{c}46 \\
(92)\end{array}$ & $50(94)$ & 0.71 & $\begin{array}{c}31 \\
(67)\end{array}$ & $38(74)$ & & $\begin{array}{c}29 \\
(63)\end{array}$ & $31(62)$ & 0.67 \\
\hline Mild pain & $\begin{array}{l}4 \\
(8)\end{array}$ & $3(6)$ & & $\begin{array}{l}15 \\
(33)\end{array}$ & $11(22)$ & 0.26 & $\begin{array}{l}16 \\
(35)\end{array}$ & 19 (38) & \\
\hline $\begin{array}{l}\text { Moderate } \\
\text { pain }\end{array}$ & $\begin{array}{c}0 \\
(0)\end{array}$ & $0(0)$ & & $0(0)$ & $2(4)$ & & $1(2)$ & $0(0)$ & \\
\hline $\begin{array}{l}\text { Severe } \\
\text { pain }\end{array}$ & $\begin{array}{c}0 \\
(0)\end{array}$ & $0(0)$ & & $0(0)$ & $0(0)$ & & $0(0)$ & $0(0)$ & \\
\hline \multicolumn{10}{|l|}{ Glutes } \\
\hline No pain & $\begin{array}{c}43 \\
(86)\end{array}$ & $51(96)$ & 0.09 & $\begin{array}{c}36 \\
(82)\end{array}$ & $43(84)$ & 0.88 & $\begin{array}{c}40 \\
(85)\end{array}$ & $43(86)$ & 1.00 \\
\hline Mild pain & $\begin{array}{c}7 \\
(14)\end{array}$ & $2(4)$ & & 8 (19) & 7 (14) & & 7 (15) & 7 (14) & \\
\hline $\begin{array}{l}\text { Moderate } \\
\text { pain }\end{array}$ & $\begin{array}{c}0 \\
(0)\end{array}$ & $0(0)$ & & $0(0)$ & $1(2)$ & & $0(0)$ & $0(0)$ & \\
\hline $\begin{array}{l}\text { Severe } \\
\text { pain }\end{array}$ & $\begin{array}{c}0 \\
(0) \\
\end{array}$ & $0(0)$ & & $0(0)$ & $0(0)$ & & $0(0)$ & $0(0)$ & \\
\hline
\end{tabular}


A

B
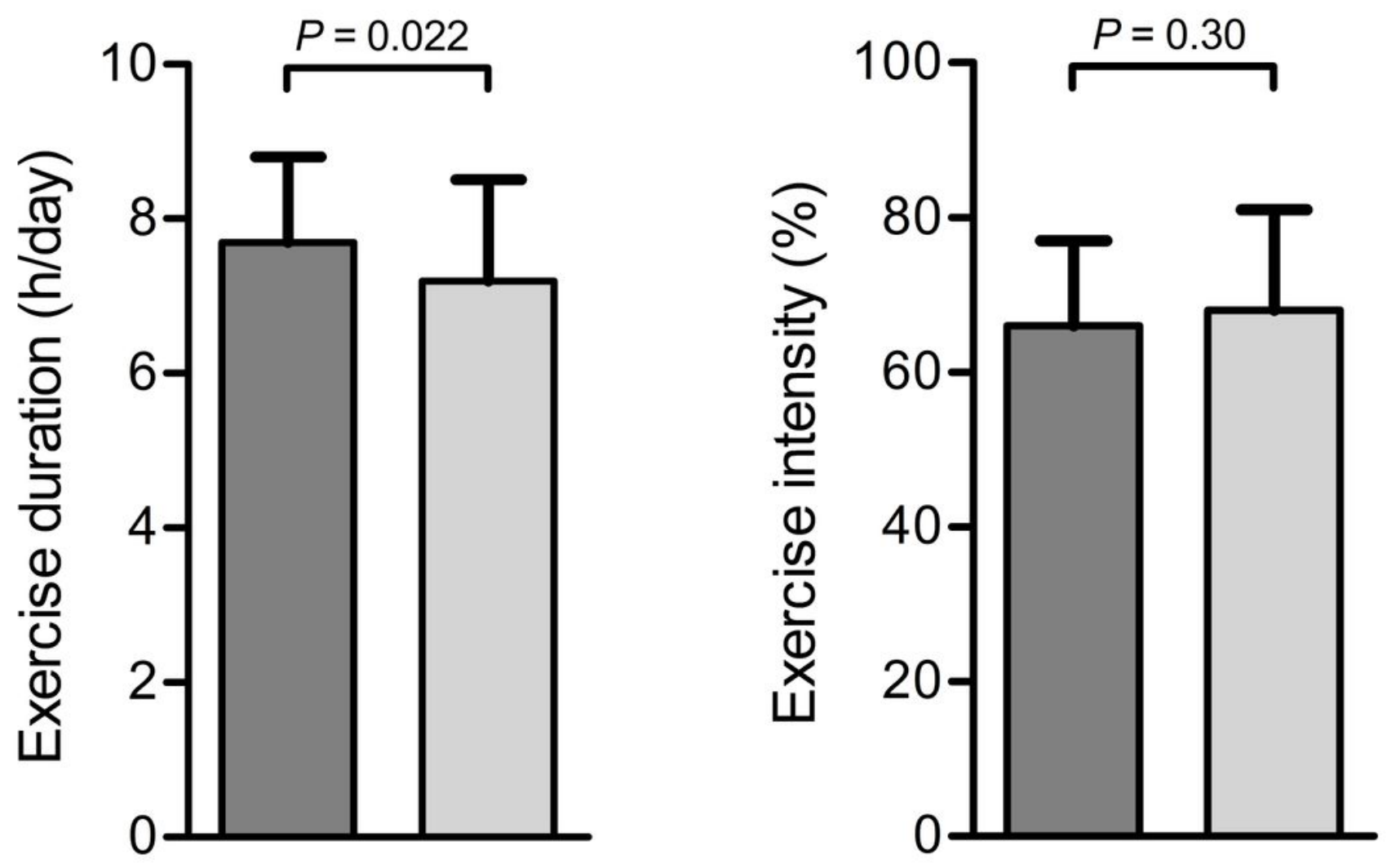

Figure 1

Bar charts for exercise duration (h/day) and exercise intensity (\% from HRmax) on day 1 . The exercise duration was $0.5 \mathrm{~h}$ longer for the protein group (dark grey) compared to the placebo group (light grey) ( $P$ $=0.022$ ), whereas no significant difference between groups was observed for exercise intensity (\% from maximal heartrate $(\mathrm{HRmax})(P=0.30)$. 

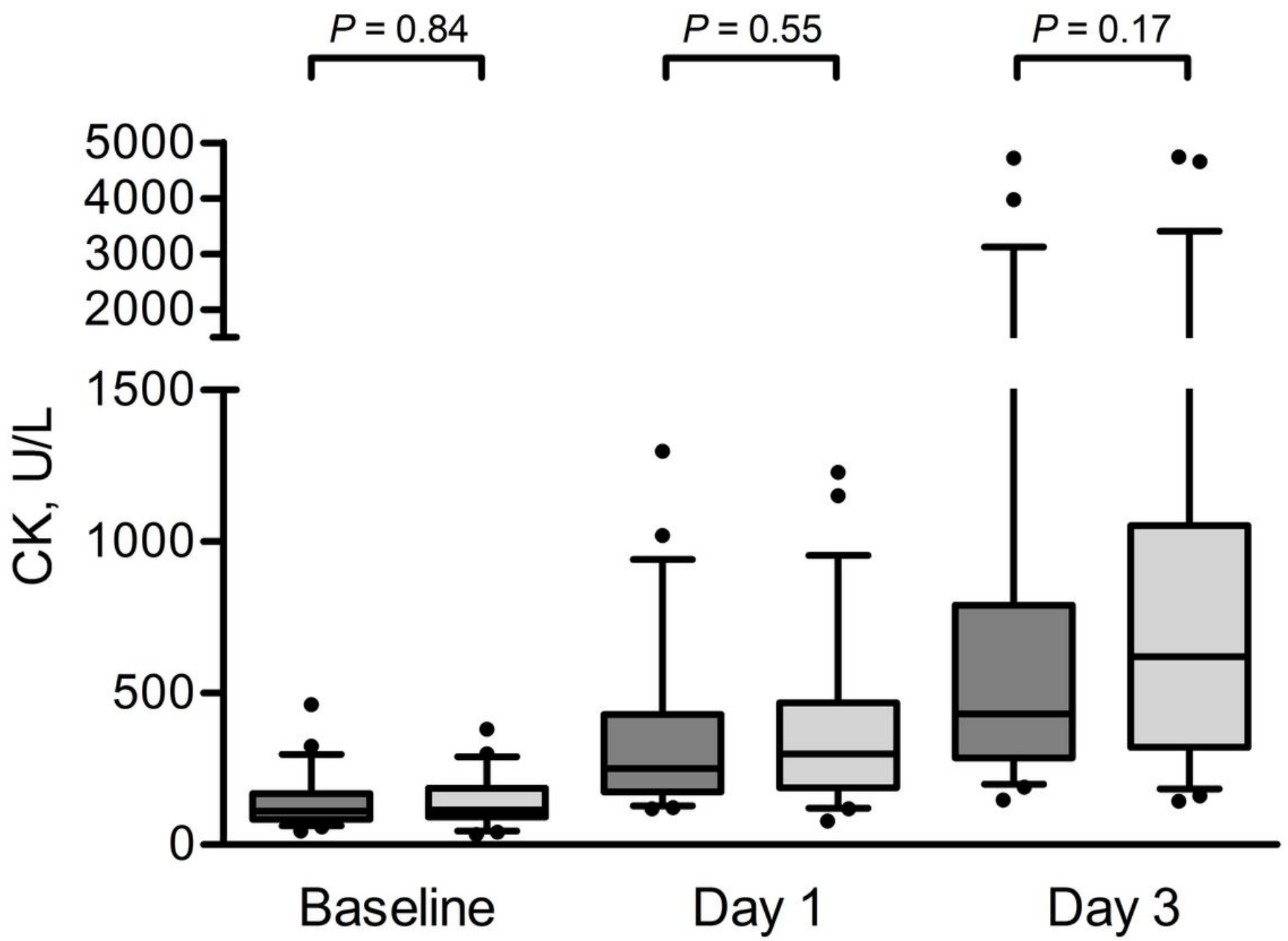

Figure 3

Box and whisker plots for CK at baseline, after day 1 and after day 3. The box and whisker plots represent the median, interquartile range, 5-95\% percentile (upper and lower whiskers) and outliers (dots) of creatine kinase (CK), for the protein group (dark grey) and the placebo group (light grey). Prolonged walking resulted in elevated $\mathrm{CK}$ levels in both groups $(P<0.001)$. No significant differences were observed between the groups at the different time points (all $P>0.05$ ).

\section{Supplementary Files}

This is a list of supplementary files associated with this preprint. Click to download.

- CONSORT2010Checklist.doc

- TIDieRChecklistWord.docx

- CONSORT2010Checklist.doc 
- TIDieRChecklistWord.docx

Page 18/18 